\title{
Diethylpropion and mazindol: An end to the discussion?
}

Rosa Camila lucchetta ${ }^{1 *}$, Bruno Salgado Riveros ${ }^{1}$, Roberto Pontarolo ${ }^{1}$, Rosana Bento Radominski ${ }^{2}$, Michel Fleith Otuki ${ }^{3}$, Fernando Fernandez-Llimos ${ }^{4}$, Cassyano Januário Correr ${ }^{1}$

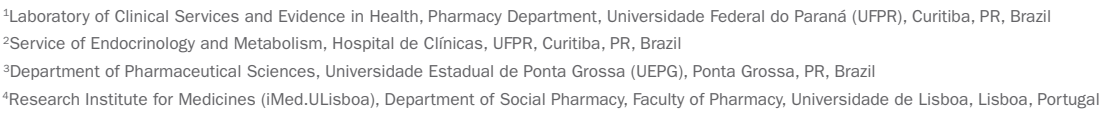

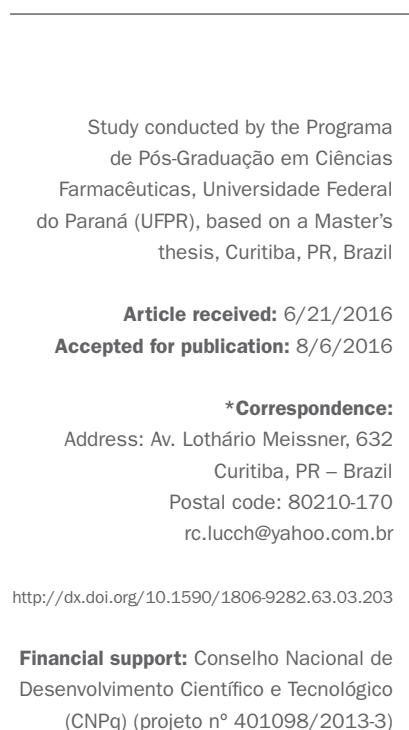

(CNPq) (projeto n ${ }^{\circ}$ 401098/2013-3)

\section{INTRODUCTION}

Approximately $39 \%$ of adults were overweight or obese in 2014 and therefore subject to associated comorbidities such as type 2 diabetes mellitus (T2DM), hypertension and coronary artery disease, and high mortality. ${ }^{24}$

In addition to the prevention of overweight and obesity with lifestyle changes, there is a recommendation for behavioral, dietary, pharmacological or surgical treatment, aiming at reducing weight and associated risk factors. ${ }^{15}$ Pharmacological options have been studied and are available in the market since the 1950s. Despite its long history, pharmacotherapy is still the subject of extensive scientific and political debate: starting with questionable safety and effectiveness, given that in nearly 70 years the registration of many medicines has been canceled by the major regulatory agencies due to the increased incidence of psychiatric and cardiac disorders, as well as other events attributed to the therapeutic or abusive use of rimonabant, fenfluramine, sibutramine and more. ${ }^{16}$

A closer look at the current regulatory status of antiobesity drugs will demonstrate that there are many disagreements between the Brazilian Health Surveillance Agency (Anvisa, in the Portuguese acronym), the Food and Drug Administration (FDA) and the European Medicines
Agency (EMA). While the EMA recommends approval of naltrexone+bupropion, orlistat and liraglutide only, the FDA authorizes these three and other drugs, namely: diethylpropion, benzphetamine, phendimetrazine, phentermine, phentermine+topiramate and lorcaserin. ${ }^{8}$

A plausible explanation for the different licensing practices between these two agencies may be associated with the poor quality of the published primary and secondary studies. Although there are differences between the FDA and EMA regarding the authorization process, both are strongly dependent on the quality of randomized clinical trials (RCTs). ${ }^{13,21}$ Discontinuation of treatment, small sample size, low methodological quality, and high level of heterogeneity in meta-analyzes are the most common limitations. ${ }^{3,11,14}$

\section{Appetite suppressants in BraziL}

For many years, Brazil was mentioned as one of the largest consumers of appetite suppressants in the world, with evidence of the irrational use of this class of medicine. ${ }^{10,18,20}$ Martins et al. conducted a cross-sectional study that included 664 college students and identified a high proportion of use of appetite suppressants with no indication or medical prescription. ${ }^{17}$ Mota et al., in a phar- 
macoeconometric study (2009-2011), reveal that the consumption of diethylpropion, fenproporex, mazindol and sibutramine did not follow the geographical distribution of overweight or obese individuals, suggesting that there are problems in the use of these appetite suppressants in the Brazilian capitals and the Federal District regarding consumption associated with other drugs - considered illegal by Anvisa - and also the therapeutic indication of use of these products. ${ }^{19}$

The irrational use of appetite suppressants led the Anvisa Collegiate Board to present technical-scientific arguments related to the efficacy and safety issues of the appetite suppressant drugs registered in Brazil. These data were presented at a Public Hearing, held on February 23, 2011, at the Anvisa auditorium. The technical note justifies why the appetite suppressant drugs diethylpropion, fenproporex, mazindol and sibutramine no longer present an adequate benefit-risk ratio, making the permanence of these products in the Brazilian market unfeasible. The irrational use of appetite suppressants in Brazil, together with the lack of robust evidence on the safety and efficacy of these drugs, led Anvisa, in that same year, to cancel the registration of diethylpropion, fenproporex and mazindol (Resolution - RDC No. 52 , on October 6,2011$).{ }^{7}$ However, the determination caused much debate among professional associations, societies and councils: the Brazilian Association for the Study of Obesity and Metabolic Syndrome (Abeso - Associação Brasileira para o Estudo da Obesidade e da Síndrome Metabólica) and the Brazilian Society of Endocrinology and Metabology argue that this positioning is leaving a large number of obese without treatment. According to Abeso, patients who are contraindicated for bariatric surgery and who have lower purchasing power are the most disadvantaged, as they have few drug options for treatment and insufficient financial resources to acquire orlistat. ${ }^{4}$ In a letter dated August 5, 2014, the entity communicated its opinion to the Federal Senate, which withdrew the resolution mentioned above, through Legislative Decree No. 273 , dated September 4, 2014. ${ }^{5}$ As a result, on September 25,2014 , RDC $50^{6}$ was issued, providing for measures to control the marketing, prescription and distribution of drugs containing diethylpropion, fenproporex, mazindol and sibutramine, their salts and isomers, and by-products.

By means of RDC 50/2014, Anvisa therefore authorizes the trade, prescription and distribution of diethylpropion, fenproporex and mazindol upon formal registration of new medications, since the Senate does not have the power to suspend the cancelation of drug registrations, despite repealing RDC 52/2011. So far, there is no registra- tion in Brazil for diethylpropion, fenproporex or mazindol. The only antiobesity drugs approved for this purpose are orlistat, sibutramine and liraglutide. Recently, the Federal Senate approved a project (PLC 61/2015) that transforms into law the authorization for the production, sale and consumption of medicines that have sibutramine, diethylpropion, fenproporex and mazindol in its composition. The bill will be forwarded to the Chamber of Deputies and then to the President of the Republic.

According to Muir Gray (1997) apud Brownson et al., ${ }^{9}$ the absence of excellent evidence should not render decision-making by health surveillance impossible. What is needed is the best evidence available that contributes to risk management, thus enhancing the healthy use of medicines in the country.

The importance of systematic reviews followed by direct meta-analysis and comparison of multiple pharmacological treatments involving different subgroups of obese or overweight individuals, as well as articles including controlled studies with long-term results, is well-established to guide clinical decision-making and the guidelines issued by regulatory entities.

\section{BUT, AFTER ALL, WHAT DO CLINICAL TRIALS INDICATE?}

For that matter, a recent systematic review followed by meta-analyzes included 25 randomized controlled trials (RCTs) evaluating efficacy, safety and metabolic biomarkers of diethylpropion $(n=13)$, mazindol $(n=13)$ and fenproporex $(n=1) \cdot{ }^{17}$ Only three studies had long follow-up (180 days or more), two studies performed head-to-head comparisons, two studies performed intention-to-treat (ITT) analyzes, and two studies were conducted in Brazil.

Most RCTs presented a high risk of bias, with a predominance of other sources of bias (conflict of interest for funding by a for-profit organization) and the report of selective outcomes (metabolic biomarkers such as blood pressure, lipids, serum glucose, heart rate). Decision makers should pay special attention to such biases. In the first case, financing by for-profit companies is particularly important, since other studies have already identified differences in results between sponsored and non-sponsored trials, contributing to a likelihood of publication bias. An observational study with 370 RCTs found that

a Muir Gray JA. Evidence-based healthcare: how to make health policy and management decisions. London: Churchill Livingstone; 1997. 
trials funded by for-profit organizations were significantly more likely to recommend the trial drug compared to trials funded by non-profit organizations. Logistic regression analysis indicated that funding was one of the significant predictors of conclusions. ${ }^{1}$ In the second case, the absence of adequate description of metabolic biomarkers has implications for evaluation of both efficacy and safety. For registration, the FDA requires the drug to show evidence of improvement in metabolic biomarkers, including blood pressure, lipids and blood glucose, ${ }^{22}$ which corroborates with therapeutic guidelines for obesity that recommend that the choice of pharmacotherapy take into account the profile of comorbidities. ${ }^{2}$ As for safety, noradrenergic action drugs have a known potential to increase heart rate. Therefore, selective reporting of these data should be interpreted with caution.

Most of the meta-analyzes were small, which may compromise the validity of the conclusions and the assessment of heterogeneity (direct meta-analyzes). A study conducted by von Hippel showed that the identification of true heterogeneity decreases as the number of studies decreases. Despite this, there is no consensus regarding the minimum number of studies to be included in a meta-analysis. ${ }^{23}$ A possible heterogeneity in the meta-analysis not only reduces the consistency of the conclusions, but also can mask the identification of inconsistency in meta-analysis networks. ${ }^{12}$ The lack of evidence from primary studies also hinders inconsistency evaluations (meta-analysis networks).

Considering short-term treatments ( $<180$ days), both direct meta-analyzes and meta-analysis networks indicated diethylpropion and mazindol as superior to placebo for body weight change. However, short-term treatment studies reporting a reduction of $5 \%$ or $10 \%$ of body weight were not identified. This outcome is of real importance for evaluating the efficacy of antiobesity treatments, since a reduction of $\geq 5 \%$ of body weight in six months is recommended. ${ }^{15}$ Mazindol was associated with discontinuation due to adverse reaction (direct meta-analysis and meta-analysis network). No serious adverse reactions were identified, either qualitatively or quantitatively. The probable reactions associated with the use of diethylpropion were dry mouth and drowsiness and, for mazindol, constipation and insomnia.

Long-term treatments ( $\geq 180$ days) resulted in favorable analyses only for diethylpropion (compared to placebo), both by direct meta-analysis and meta-analysis network for change of body weight, change in waist circumference, and $5 \%$ and $10 \%$ weight reduction. In addi- tion, no association between treatments and presence of adverse reaction or discontinuation due to adverse reaction was identified.

Therefore, due to the predominance of high risk of bias and lack of important outcomes for the evaluation of antiobesity therapy, the evaluated drugs do not present sufficient evidence to be considered effective for the treatment of obesity, which corroborates the decision by Anvisa. However, no robust safety data have been identified to corroborate their withdrawal from the market.

\section{RECOMMENDATION FOR FUTURE STUDIES}

Future RCTs could perform further head-to-head analysis, with outcomes reporting changes in waist circumference, body weight change, participants with $5 \%$ and $10 \%$ weight reduction and metabolic biomarkers (blood pressure, lipids and carbohydrates) over 3, 6, 9 and 12 months. Population subgroups included in several trials that have potential for further analyses in future studies are obese and overweight adults with no comorbidities, obese adults with DMT2, overweight adults without DMT2, obese and overweight adults with hypertension, and children and adolescents without comorbidities.

\section{Conflict of Interest}

The authors declare no conflict of interest.

\section{Resumo}

Anfepramona e mazindol: um fim à discussão?

A farmacoterapia antiobesidade ainda é alvo de amplo debate científico e político; não por acaso, já que há pouca confiabilidade tanto no âmbito dos estudos primários quanto no dos secundários, seja pelo reduzido tamanho amostral, seja pela elevada heterogeneidade e/ou pela baixa qualidade metodológica. Por muitos anos, o Brasil foi mencionado como um dos maiores consumidores de inibidores de apetite do mundo, com evidências de uso irracional dessa classe de medicamentos. Portanto, o país foi palco de debate que dividiu a Agência Nacional de Vigilância Sanitária (Anvisa) e as sociedades médicas quanto à manutenção do registro de anfepramona (dietilpropiona), mazindol e femproporex. Nesse contexto, o presente comentário apresenta novos argumentos para essa discussão e ainda recomendações para estudos futuros.

Palavras-chave: obesidade, perda de peso, resultado do tratamento, prática clínica baseada em evidências. 


\section{References}

1. Als-Nielsen B, Chen W, Gluud C, Kjaergard LL. Association of funding and conclusions in randomized drug trials: a reflection of treatment effect or adverse events? JAMA. 2003; 290(7):921-8.

2. Apovian CM, Aronne LJ, Bessesen DH, McDonnell ME, Murad MH, Pagotto $\mathrm{U}$, et al. Pharmacological management of obesity: an endocrine society clinical practice guideline. J Clin Endocrinol Metab. 2015; 100(2):342-62.

3. Arterburn DE, Crane PK, Veenstra DL. The efficacy and safety of sibutramine for weight loss: a systematic review. Arch Intern Med. 2004; 164(9):994-1003.

4. Abeso - Associação Brasileira para o Estudo da Obesidade e da Síndrome Metabólica. Comunicados Oficiais; 2011 [cited 2014 Mar 1]. Available from: http://www.abeso.org.br/comunicado/comunicados-antigos

5. Brasil. Decreto legislativo n. 273, de 4 de setembro de 2014. Available from: http://www2.camara.leg.br/legin/fed/decleg/2014/decretolegislativo-2734-setembro-2014-779343-publicacaooriginal-144957-pl.html.

6. Brasil. Resolução da Diretoria Colegiada - RDC n. 50, de 25 de setembro de 2014 [cited 2015 Mar 1]. Available from: http://pesquisa.in.gov.br/imprensa/jsp/ visualiza/index.jsp?data $=26 / 09 / 20148$ jornal $=1$ \& pagina $=668$ total Arquivos $=240$

7. Brasil. Resolução da Diretoria Colegiada - RDC n. 52, de 6 de outubro de 2011 Dispõe sobre a proibição do uso das substâncias anfepramona, femproporex e mazindol, seus sais e isômeros, bem como intermediários e medidas de controle da prescrição e dispensação de medicamentos que contenham a substância sibutramina, seus sais e isômer; 2011 [cited 2015 Mar 12]. Available from: http://www.anvisa.gov.br/hotsite/anorexigenos/pdf/RDC\%2052-2011\%20 DOU\%2010\%20de\%20outubro\%20de\%202011.pdf

8. Bray GA, Ryan DH. Update on obesity pharmacotherapy. Ann N Y Acad Sci. $2014 ; 1311: 1-13$

9. Brownson RC, Fielding JE, Maylahn CM. Evidence-based public health: a fundamental concept for public health practice. Annu Rev Public Health. 2009; 30(1):175-201.

10. Carneiro Mde F, Guerra AA Jr, Acurcio FA. [Prescription, dispensing, and regulation of psychoactive anorexigenic drugs in Belo Horizonte, Minas Gerais, Brazil]. Cad Saude Publica. 2008; 24(8):1763-72.

11. Chilton M, Dunkley A, Carter P, Davies MJ, Khunti K, Gray LJ. The effect of antiobesity drugs on waist circumference: a mixed treatment comparison. Diabetes Obes Metab. 2014; 16(3):237-47.

12. Dias S, Welton NJ, Sutton AJ, Caldwell DM, Lu G, Ades AE. Evidence synthesis for decision making 4: inconsistency in networks of evidence based on randomized controlled trials. Med Decis Making. 2013; 33(5):641-56.
13. Eriksson R, Aagaard L, Jensen LJ, Borisova L, Hørlück D, Brunak S, et al. Discrepancies in listed adverse drug reactions in pharmaceutical product information supplied by the regulatory authorities in Denmark and the USA. Pharmacol Res Perspect. 2014; 2(3):e00038.

14. Fabricatore AN, Wadden TA, Moore RH, Butryn ML, Gravallese EA, Erondu NE, et al. Attrition from randomized controlled trials of pharmaco logical weight loss agents: a systematic review and analysis. Obes Rev 2009; 10(3):333-41.

15. Jensen MD, Ryan DH, Apovian CM, Ard JD, Comuzzie AG, Donato KA, et al.; American College of Cardiology/American Heart Association Task Force on Practice Guidelines; Obesity Society. 2013 AHA/ACC/TOS guideline for the management of overweight and obesity in adults: a report of the American College of Cardiology/American Heart Association Task Force on Practice Guidelines and The Obesity Society. Circulation. 2014; 129(25 Suppl. 2):S102-38.

16. Li M-F, Cheung BM. Rise and fall of anti-obesity drugs. World J Diabetes. 2011; 2(2):19-23.

17. Lucchetta R, Riveros B, Pontarolo R et al. Systematic review and meta-analysis of the efficacy and safety of amfepramone and mazindol as a monotherapy for the treatment of obese or overweight patients. Clinics, 2017 (in press).

18. Martins MC, Souza Filho MD, Moura FS, Carvalho JSR, Müller MC, Neves $\mathrm{RV}$, et al. Use of anti-obesity drugs among college students. Rev Assoc Med Bras. 2011; 57(5):570-6

19. Mota DM, Silva-Jr GG. [Evidence for the use of appetite suppressant drugs in Brazil: a pharmacoeconometric study]. Rev Assoc Med Bras. 2012; 58(1):88-94

20. Nappo SA, Tabach R, Noto AR, Galduróz JCF, Carlini EA. Use of anorectic amphetamine-like drugs by Brazilian women. Eat Behav. 2002; 3(2):153-65.

21. Tafuri G, Stolk P, Trotta F, Putzeist M, Leufkens HG, Laing RO, et al. How do the EMA and FDA decide which anticancer drugs make it to the market? A comparative qualitative study on decision makers' views. Ann Oncol. 2014; 25(1):265-9.

22. U.S. Department of Health and Human Services, Food and Drug Administration (FDA), Center for Drug Evaluation and Research (CDER) Guidance for Industry Developing Products for Weight Management (Draft Guidance); 2007

23. von Hippel PT. The heterogeneity statistic I(2) can be biased in small metaanalyses. BMC Med Res Methodol. 2015; 15:35.

24. WHO - World Health Organization. Global Health Observatory [Internet] Overweight and obesity. 2014 [cited 2015 Nov 9]. Available from: http:// www.who.int/gho/ncd/risk_factors/overweight/en/. 